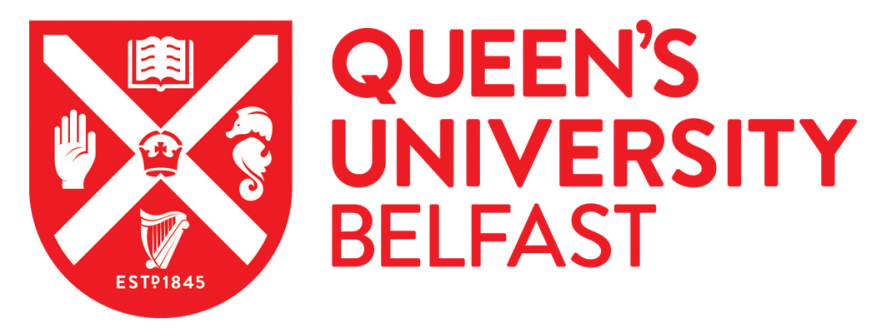

\title{
Long-term archaeological perspectives on new genomic and environmental evidence from early medieval Ireland
}

Hannah, E., \& McLaughlin, T. (2019). Long-term archaeological perspectives on new genomic and environmental evidence from early medieval Ireland. Journal of Archaeological Science, 106, 23-28. https://doi.org/10.1016/j.jas.2019.04.001

Published in:

Journal of Archaeological Science

Document Version:

Peer reviewed version

Queen's University Belfast - Research Portal:

Link to publication record in Queen's University Belfast Research Portal

Publisher rights

Copyright 2019 Elsevier

This manuscript is distributed under a Creative Commons Attribution-NonCommercial-NoDerivs License

(https://creativecommons.org/licenses/by-nc-nd/4.0/), which permits distribution and reproduction for non-commercial purposes, provided the author and source are cited.

\section{General rights}

Copyright for the publications made accessible via the Queen's University Belfast Research Portal is retained by the author(s) and / or other copyright owners and it is a condition of accessing these publications that users recognise and abide by the legal requirements associated with these rights.

Take down policy

The Research Portal is Queen's institutional repository that provides access to Queen's research output. Every effort has been made to ensure that content in the Research Portal does not infringe any person's rights, or applicable UK laws. If you discover content in the Research Portal that you believe breaches copyright or violates any law, please contact openaccess@qub.ac.uk. 
2

3 Long-term archaeological perspectives on new genomic and environmental

4 evidence from early medieval Ireland

5 Emma Hannah and Rowan McLaughlin*

6

7 School of Natural and Built Environment, Queen's University Belfast

$8 \quad{ }^{*}$ Corresponding author r.mclaughlin@qub.ac.uk

9

Highlights

- A database containing over 8000 radiocarbon dates of human activity in Ireland has been assembled

- The data have been contextualised for the period 400 to $1200 \mathrm{CE}$ (1600 to $800 \mathrm{yrs}$ $\mathrm{BP})$, revealing a pronounced oscillation between intensifying and declining activity throughout the landscape

- We suggest a preliminary long-term population model for Ireland via comparison with later and earlier trends and demographic events

- We review recent genetic evidence of population dynamics in Ireland, and posit haplotype admixture events took place in the context of population decline

- These results mirror recent palaeoisotope studies of intensification

\section{Abstract}

25 Using archaeological data, this paper investigates past population trends in Ireland as a 26 response to recent genomic studies that have identified admixture signals in the genomes of 27 Irish people caused by historically-recorded migration events. Among these was Norse 
settlement in the $9^{\text {th }}-10^{\text {th }}$ centuries CE, which has a greater than expected signal in the contemporary population of the island. Here, we contextualise these discoveries using a large database of recently discovered archaeological sites with radiocarbon dates that we have analysed using Kernel Density Estimation techniques. We argue that the Viking migrations occurred following a 300-year period of population decrease in Ireland. This new, data-driven synthesis of the archaeological record contrasts with previous accounts of early medieval Ireland as a period of ever-growing expansion and progression. However, this new interpretation is also aligned to evidence for economic and environmental change, including recent discoveries concerning the soil nitrogen cycle and agricultural intensification. We compare historical evidence for Viking migrations to later episodes of migration between Britain and Ireland, where more details are known about the size of the incoming groups, ultimately wishing to confront the opinion that past population sizes cannot be fathomed for cultures without documentary records. Through comparison with historic analyses and census records, we make broad estimates of absolute population size in Ireland since prehistoric times, including during these demographic events, and argue that much value is added to genomic evidence for migration when these points in time are contextualized in terms of evolving population trends.

\section{Keywords}

Population size, demographics, genomics, archaeology, early medieval, Ireland

\section{Introduction}

Human population dynamics is an important window into the mechanisms underpinning societies, informing us about yet more fundamental processes including environmental pressure, evolution, epidemiology and the availability of resources. Human population size in particular has had a major influence on ecosystem function today and at least since the MidHolocene (e.g. Ruddiman, 2003). Until recently, the long-term history of human population was guesswork as historic records only cover recent centuries. However, independent work in ancient DNA, modern genomics, paleoecology, and data-driven archaeology are together beginning to address this gap in our understanding. 
To this end, this paper forms an archaeologists' response to the recently published studies of the genomic structure of modern Irish and British populations (Byrne et al., 2018; Gilbert et al., 2017), focusing on how archaeometric and genomic data can together advance our understanding of the dynamics of the early medieval population in Ireland (400 to $1200 \mathrm{CE}$ ).

We also discuss recently-published evidence that the archaeological signals of population change are present in the Holocene nitrogen cycle in Ireland, and look before and after the early medieval period, contextualising these trends over the longer-term.

Our particular focus is on Ireland (Figure 1), uniquely suited to this study because the growth of the 'Celtic Tiger' economy in the 1990s and 2000s led to an extraordinary number of archaeological rescue excavations of quasi-random samples of the landscape, unbiased by the pre-existing research interests of archaeologists (Armit et al., 2014; McLaughlin et al., 2016). The basic premise underlying the use of archaeology in this way is that larger human populations tend to generate more detectible archaeological signals than smaller ones, and frequency of archaeological materials can be used to model population trends if certain conditions are met and the data are treated appropriately (Edinborough et al., 2017; Timpson et al., 2014).

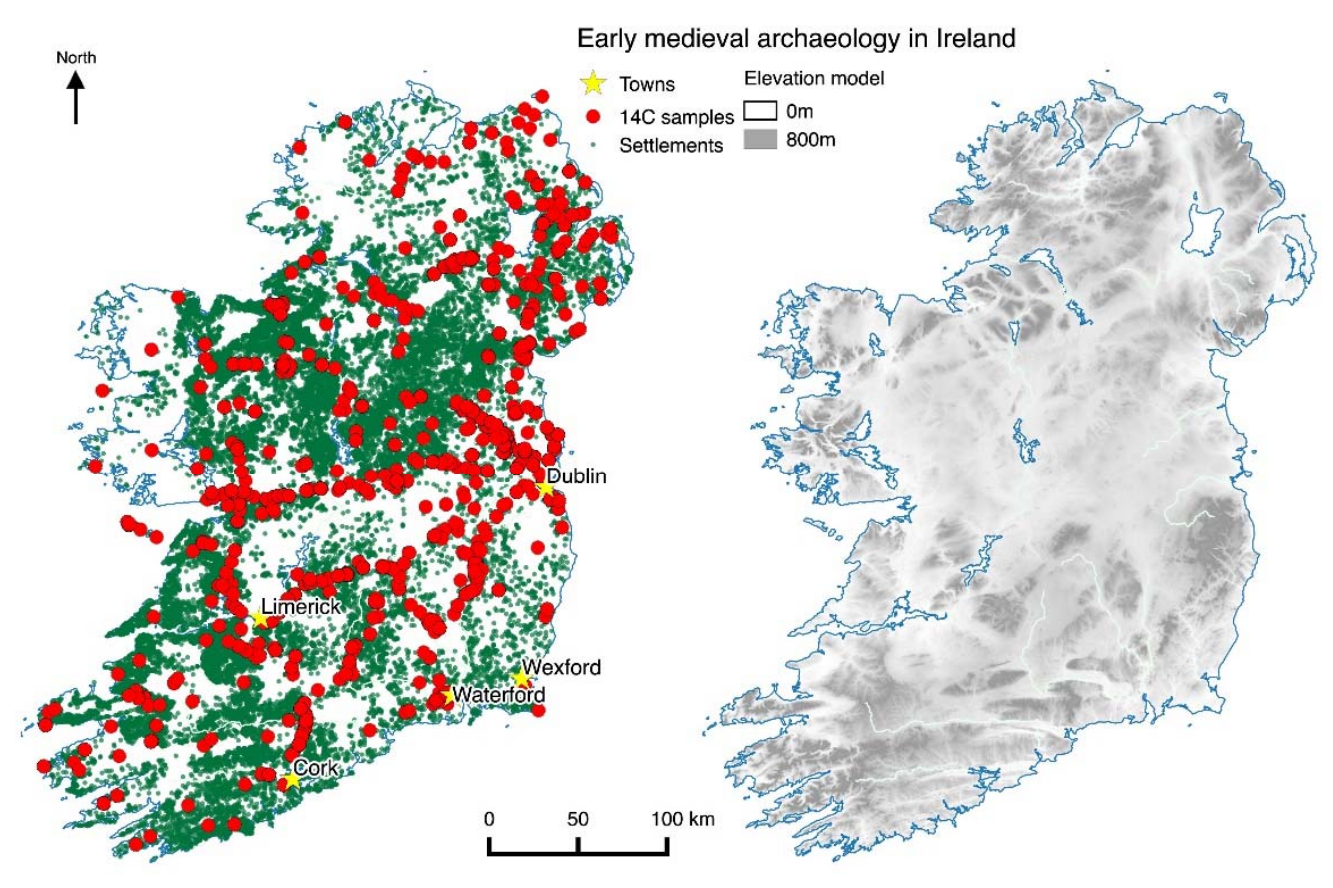
indicating that everywhere in lowland Ireland was heavily settled, and the extent that this landscape has been 
Genomic studies of population structure are made possible by haplotypes (blocks of genetic information) that are shared within and across populations in patterns that uniquely segregate with discrete localities, or, by proxy, certain points in time. New approaches differ from previous attempts to come to terms with Ireland's genetic landscape because they make use of new methods that analyse the entire genome of living people, and can predict geographical affinity using genetic data alone, implying that local genetic patterns have persisted throughout many generations. It seems that the main effect of the limited scale of migration and exogamy in human history is that people from nearby regions tend to be more closely related than people from further away. In Britain and Ireland, this is exemplified by the kinship shared across the shortest sea crossing between northeast Ireland and southwest Scotland, and the genetic similarities between English people and those of Ireland's eastern coast. Genomic studies (Byrne et al., 2018; Gilbert et al., 2017) have been able to estimate when episodes of migration occurred by modelling the decay of haplotypes shared between modern Irish individuals and modern proxies for migrating individuals. The independent insight from modern genomics presents stimulating archaeological implications, and an opportunity to tackle tricky problems of migration and absolute population in past societies through collaborative dialogue.

These genomic signals offer a tantalising glimpse at a rather murky period in Ireland's past. Through admixture modelling, the origins of genomic affinities between Irish and Scandinavian populations can be dated to during the Viking Age, 900-1200 CE, (Byrne et al., 2018; Gilbert et al., 2017; Leslie et al., 2015). Former estimates of Viking ancestry in Ireland based on Y-chromosome haplotypes detected little presence of Scandinavian-type haplotypes (McEvoy et al., 2006). For a time, and bolstered by the inadequately-powered Y-chromosome haplotype data, narratives of acculturation between native and small numbers of incoming Scandinavian immigrants were popular (e.g. Knudson et al., 2012), but these models must now be revised. The size of the contemporary native population is a key parameter which must be investigated in order to understand the causes, scales and effects of the migrations. For this we turn to an analysis of the archaeological record.

\section{Methods}

We built a database of radiocarbon data derived from archaeological excavations in Ireland $(\mathrm{n}=8805$ dates, see supplementary data) drawing upon other published sources (Bevan et al., 
2017; Chapple, 2015; McLaughlin et al., 2018; McLaughlin, 2018). Each entry in the database consisted of a radiocarbon age determination $\left({ }^{14} \mathrm{C}\right.$ yrs \pm standard deviation), and geographic attributes. For early medieval samples (locations shown in Figure 1), the database also included categorical variables describing the kind of material dated and the context in which it was originally found. These were evaluated by reviewing the excavation reports and other metadata originally published with each date; although this process involved a degree of subjectivity, broad categories were chosen to minimise misclassification. We removed the small number of marine samples from the dataset to avoid the additional analytical complexity of their calibration. To process these data and develop density models on a calendar time scale, we used kernel density estimation (KDE) (Bronk Ramsey, 2017; McLaughlin, 2018). This method calculated the probability density of human activity in Ireland, or for each context or geographical area, with a bandwidth of 30 years. We expressed calibration uncertainty in the KDE by bootstrapping 2000 individual KDE models built from repeated 'Monte Carlo' random samples drawn from the probability density functions of each radiocarbon date (see McLaughlin, 2018) using the IntCal13 (Reimer et al., 2013) calibration dataset; samples derived from non-atmospheric ${ }^{14} \mathrm{C}$ reservoirs were excluded from the analyses. To check the data were sufficiently powered, we repeated the density modelling process using multiple permutations of the dataset, using random sampling with replacement. The rate of population growth or decline can be determined from the gradient of the KDE; sudden events like migrations of large numbers of people would manifest in the models as abrupt change to the kernel density.

\section{Results}

\subsection{Archaeological proxy evidence for population trends}

The density models (Figure 2) reveal widespread decline spanning 700 and $1100 \mathrm{CE}$, the centuries before and during the Viking migrations. There are some regional variations, but it seems the decline occurred more-or-less simultaneously throughout the island. It also manifested in every archaeological context we have studied. This is an important point because some contend that radiocarbon date densities are influenced by changes in human behaviour and research bias (Torfing, 2015). Research bias does not affect the developer-led projects that contribute the bulk of these data, but behavioural change in theory could. For example, there is a growing consensus that settlement evidence, aside from élite sites, became more ephemeral 
during these centuries due to changing building paradigms and the abandonment of ditched enclosures (FitzPatrick, 2013; O’Sullivan et al., 2014; O’Sullivan and McCormick 2017).

144 Through reducing archaeological visibility, this could explain the drop in dates from timber structures and enclosures, but not the similar slowly-reducing trend we have discovered for burials of the period. There is no evidence that burial practice changed during the period in a way that would alter the taphonomic properties of these contexts. Although a shift towards ecclesiastical (and therefore largely unexcavated) sites is a plausible explanation of the trend for burials (O’Sullivan and McCormick, 2017), it fails to adequately explain why decline occurred at the same time and at a similar rate as other activities, be it ditched enclosures, building, timber structures, or arable agriculture (Figure 2). That the signal is wholly driven by habitual practices of an entire island population changing steadily for centuries, in many manners of daily life, is unrealistic at best. Instead, we propose a hypothesis that the trends in these data are rooted in demographic changes. The proposed relationship between radiocarbon intensities and population size in archaeological cultures is not a new one and substantially powered radiocarbon datasets are becoming an accepted proxy (e.g. Bevan et al., 2017;

157 Edinborough et al., 2017; Jørgensen, 2018; Morin et al., 2018; Oh et al., 2017; Palmisano et al., 2017). Indeed, the dataset for early medieval Ireland is unrivalled in terms of data density. These trends can therefore be used to model long-term relative changes in population, and a comparison with historical data brings us a step further to modelling absolute population size. 

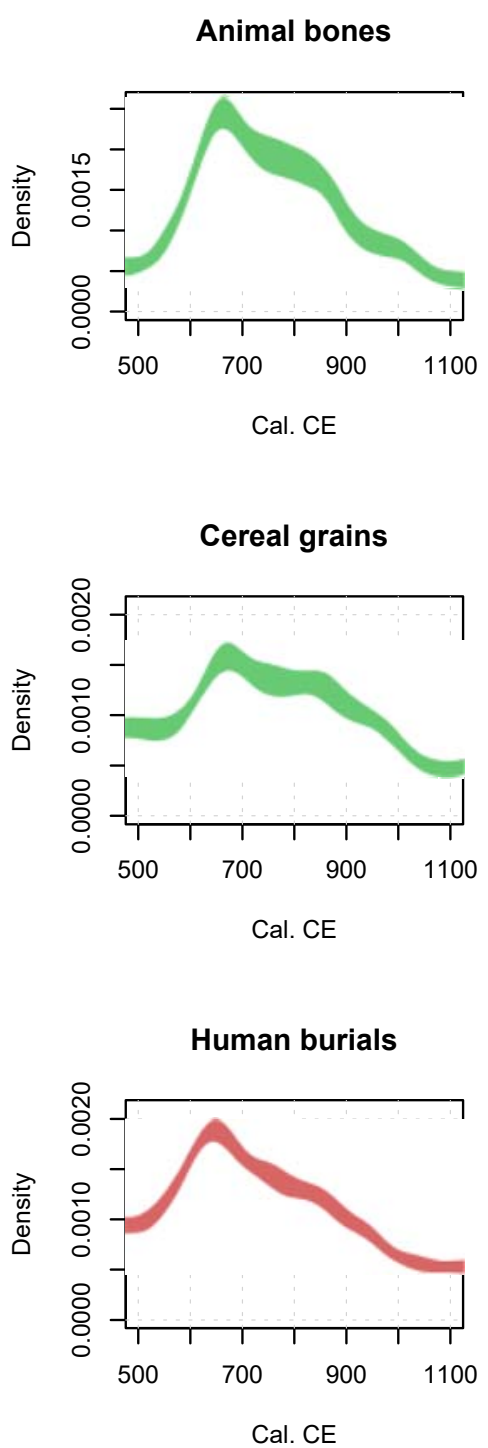

161

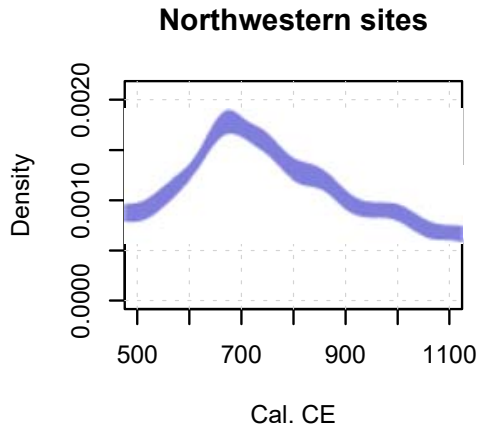

Southwestern sites

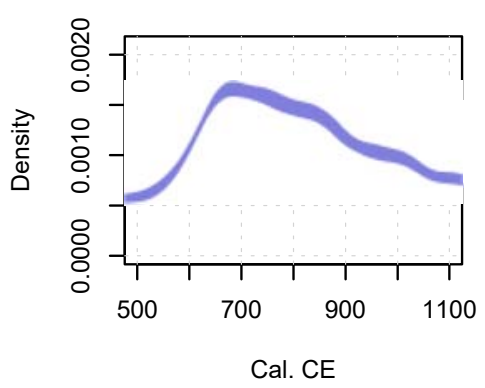

Enclosures

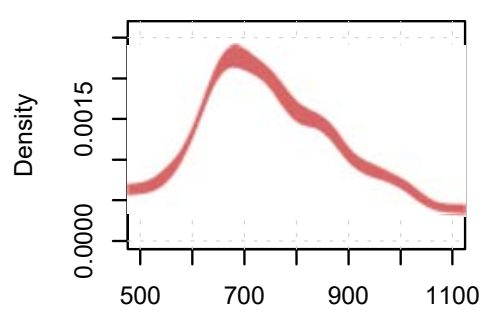

Cal. CE

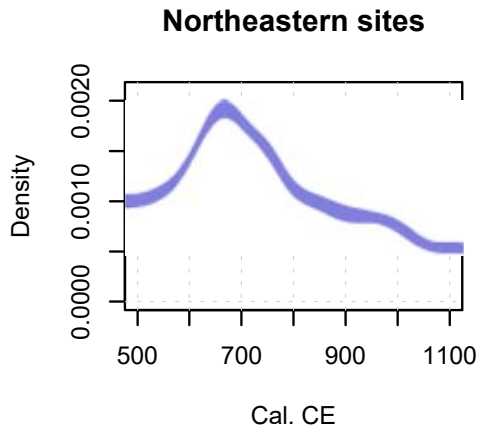

Southeastern sites

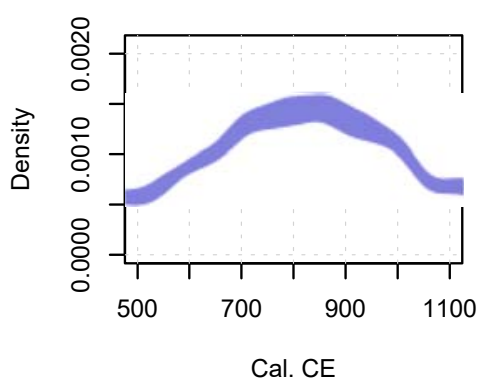

Settlement and buildings

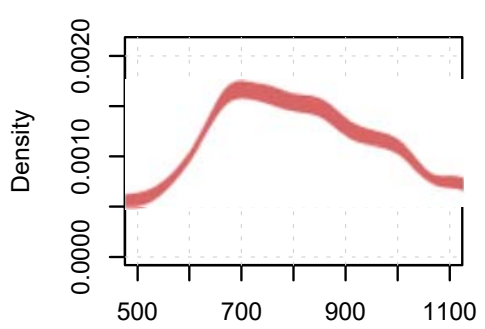

Cal. CE

Figure 2: Archaeological ${ }^{14} \mathrm{C}$ kernel density models from different kinds of sample (green), region (blue) and context (red) in Ireland

\subsection{Radiocarbon-derived population model}

In Ireland, 18th-century church records and (from 1841) censuses record past population levels, and for earlier periods, scholars of the late medieval have produced various population estimates (Supplementary Table 2). These can be compared to the archaeological radiocarbon evidence. Radiocarbon dating is seldom used by archaeologists for the post-medieval period, and so the two curves are decoupled around $1500 \mathrm{CE}$, but their intersection in the medieval provides a foothold for extrapolating population estimates back in time. 
172 This model of radiocarbon density as compared to earlier and later populations is presented in 173 Figure 3. It suggests around $680 \mathrm{CE}$, the population reached a maximum. The uncertainty of the KDE at this point in time is around \pm 25 years. The archaeological record in Ireland from this period consists of 10 s of thousands of sites (Figure 1), which as a proxy for population can be multiplied by the number of people associated with each, such as the children, dependants and servants of the élite whose archaeological traces are more visible (cf. Stout, 2017). The maximum occurred after a sustained period of growth beginning around $200 \mathrm{CE}$, after a 'Late Iron Age lull' (Coyle-McClung, 2013). The increase slowed in the $6^{\text {th }}$ century, perhaps due to the Justinian plague or a worsening climate, but soon recovered. Falling activity after $680 \mathrm{CE}$ resulted in the radiocarbon density associated with the dispersed rural population falling to $47 \%$ of its maximum at the time of the Viking migrations. A similar level of activity occurred over the subsequent centuries, 1200 to $1600 \mathrm{CE}$, when the medieval population of Ireland is estimated to number around 1,800,000 people (Cullen, 1974-5).

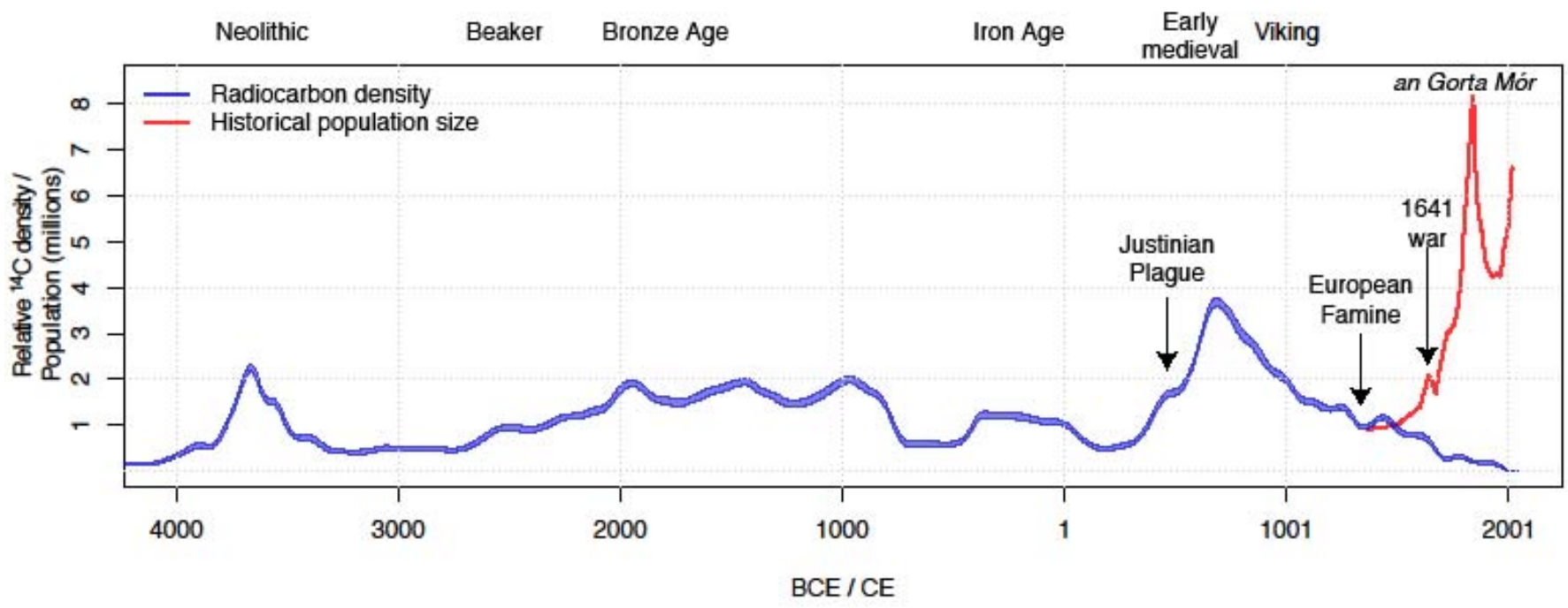

Figure 3: Density model of 14C dates from Ireland scaled to historic population levels. Indicated are major known demographic events

\subsection{Environmental impacts}

Palaeoecological data have the potential for independent insight into past human population levels. Palynological studies of Irish bogs and lakes show disparate views of the landscape, with some providing proxy evidence for agricultural intensification in the period and others 
detecting a break in cereals, continued pastoral practices, or even reduced levels of activity (Coyle-McClung, 2012). At some sites there is indication of the regrowth of scrub (Hall et al., 1993) although this is far from widespread. Many studies lack the refined chronology necessary for detailed and robust comparison with the archaeological record (Coyle-McClung, 2012). An alternative perspective on the cumulative effects of deforestation, tillage and intensive ancient animal husbandry on Ireland's nitrogen cycle have been achieved recently by Guiry et al. (2018), using the average ${ }^{15} \mathrm{~N}$ enrichment of a large sample of animal bones as a proxy for these activities. Intriguingly, the oscillating pattern of ${ }^{15} \mathrm{~N}$ enrichment matches the trends in the radiocarbon-derived population model throughout time, but especially for the early medieval period (Figure 4, cf. Guiry et al., 2018 Figures 2 and S1). Although the early medieval was not discussed by Guiry et al., their interpretation of ${ }^{15} \mathrm{~N}$ enrichment being a signal of widespread human activity is now strengthened by the evidence we present here about a reducing population during and after the period.
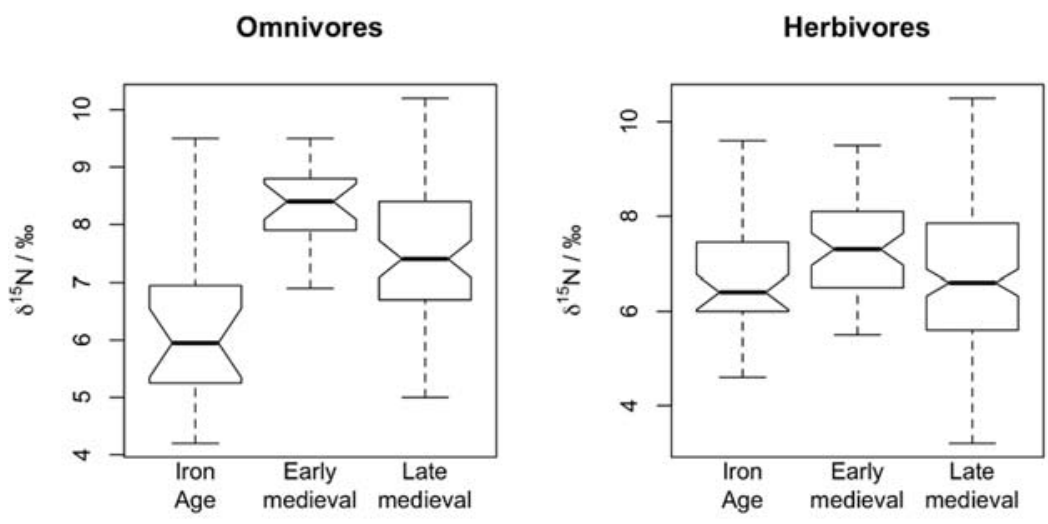

$$
\begin{aligned}
& \text { Figure 4: Guiry et al.'s (2018) data replotted, indicating that }{ }^{15} \mathrm{~N} \text { enrichment, hence overall human activity, } \\
& \text { peaked during the early medieval period in Ireland and subsequently declined }
\end{aligned}
$$

\section{Conclusions}

Existing literature on early medieval Ireland makes clear that the island contains a bountiful archaeological landscape, with traces of a distant but familiar past occurring in virtually every neighbourhood. Tens of thousands of early medieval sites can still be traced in the Irish countryside (Figure 1) in the form of stone buildings, earthworks and newly-discovered settlement and industrial sites found across the entire island (Stout, 2017). This points to a large 
rural early medieval population, and until now there was a consensus that the period was one of sustained growth in terms of its economic and social complexity (McClatchie et al., 2015; McCormick, 2008; Stout, 2017). However, the ${ }^{14} \mathrm{C}$ density suggests that this activity peaked in the late $7^{\text {th }}$ Century and the rich archaeological landscape of early medieval Ireland was largely formed long before the Viking migrations.

This perspective opens up a discussion about the number immigrants needed to create a genetic impact such as the Viking migrations did in early medieval Ireland. As a step towards quantification, we can look to the historical and archaeological records of Viking settlements established at Dublin, Cork, Waterford, Wexford, and Limerick in the $9^{\text {th }}$ and $10^{\text {th }}$ Centuries CE (Figure 1). Each of these 'towns' was comprised of streets aligned with houses, churches, mercantile and artisanal workshops as well as a burgeoning port. This was probably the whole extent of Viking settlement, as few traces have ever been found located deeper within the rural landscape. There are scattered references to the scale of the towns; annals mention thousands of Viking belligerents engaged in war, and the towns themselves were home to hundreds or thousands of families (see Supplementary Table 1). Despite these significant numbers of migrants, it remains difficult to accept that Scandinavian haplotypes became widespread in the much larger 'native' territories, and endured through subsequent centuries, unless the native population was by then relatively small. This is a view supported by the radiocarbon evidence we draw upon here, and it is possible to speculate that whatever circumstances had brought about the decline in native population continued to apply to that group, causing the signal of the incomers to become more prominent over subsequent generations.

Later phases of migration to Ireland can provide useful points of comparison for understanding such population trajectories. Among many different episodes of migration from Britain to Ireland, the best documented was the $17^{\text {th }}$-century 'Plantation' where 'native' Irish people were officially and forcibly displaced in Ulster, the northern province, with colonists from Britain. Government records from the 1630s detail that at least 6500 British adult males had moved with their families to western Ulster, matched by similar numbers in the east (Robinson, 1984: p155-171). The total population of Ulster at the time was probably around 360,000 persons (Cullen, 1974-5) and therefore the incoming British constituted as little as 3-8\% of this, assuming the British males had a family. Throughout the 'Plantation' process, the 'native' populace was forced to take residence in less productive land at the margins of the British colonies. Today, 13 generations later, the descendants of these natives and colonists comprise two genetic clusters of approximately equal size (Byrne et al., 2018; Gilbert et al., 2017) despite 
the initially smaller 'British' group. The 'British' component must therefore have had differing patterns of kinship and much enhanced fertility at the time of the migrations and over subsequent centuries.

This echoes the consequences of the Viking migrations, but unlike the forcible factors at play during the 17th Century, the early medieval decline in Ireland does not seem to have been prompted by external pressures. Nor was there a single root cause for the decline, and although the cumulative effects of political unrest, famines and plagues could take their toll (e.g. Dooley, 2007), the radiocarbon KDE between 400 and $700 \mathrm{CE}$ offers compelling evidence that early medieval society had been resilient against such events during its phase of growth. Furthermore, because the aged fall victim to plague more readily than those of child-bearing age, their long-term demographic effects tend to be over-emphasized in medieval narratives, as economic historians are keen to point out (e.g. Russell 1958, 139). We suggest instead that the long-term oscillation seen in early medieval Ireland, and indeed during earlier prehistoric phases, could represent a so-called structural-demographic cycle (Goldstone, 1991). During its phase of population growth, the secular élites in Ireland would have faced ever increasing competition with each other, as the agricultural surplus of the land was redirected to nourish a growing population. Land would have become prized though demand, and labour cheapened by over-supply. Declining living standards therefore constrained fertility rates, as did the related milieu of political strife. Into this vacuum stepped the church, whose influence steadily spread over the centuries in question (e.g. O'Sullivan and McCormick, 2017), but did not halt the loss of population. Another possible and perhaps related explanation is continued outwards migration to Britain or Europe. In particular, the strong linguistic and archaeological connections between northern Ireland and Scotland are well known (although see Cambell, 2001 for a nuanced view) and recent genomic evidence confirms a close bond with Ireland. Today's residents of southwest Scotland have greater haplotypic similarity with southern Irish populations than those now living in the north of Ireland (Byrne et al., 2018), consistent with a significant past migration that fossilised a group of Irish haplotypes in a corner of Britain, although we cannot say for sure if this happened during early medieval times.

These models of decline are speculative and not mutually exclusive. From the empirical archaeological data, we can only state that the process was gradual, drawn over some 500 years, and quite possibly imperceptible even to those living under its shadow. Under these circumstances a significant but relatively small group of Viking-Scandinavian migrants introduced to Ireland a genomic signal still detectible today. Similarly, large numbers of 
'natives' and small numbers of 'migrants' were involved in $17^{\text {th }}$ Century migrations, yet their haplotypes are now widespread. Therefore, in accessing the consequences of migration, the behaviour of the admixture groups and the existing trajectory of the 'native' population are important factors. This insight can only be gleaned from the analysis of trends inherent to historical and archaeological datasets.

Although discussion of prehistoric migration to Ireland (Cassidy et al., 2016) is beyond the scope of this paper, it is worth pointing out that each major prehistoric migration, at $3800 \mathrm{BCE}$ (Neolithic), 2500 BCE ('Beaker' period) and 400 BCE (Iron Age) occurred when the population of the island was diminished and in decline, much like the pattern that reoccurred during historic migrations. In general terms, there is archaeological evidence that substantial human populations have existed in Ireland since the Neolithic, with associated environmental impacts (cf. Guiry et al., 2018), and the evolving population densities were influenced by episodes of migration, or phases of sustained inward and outward migration, and other events that took many centuries to fully play out. The volatile population densities of recent centuries, for example the consequences of an Gorta Mór (the Great Famine and resulting century of migration, see Figure 3) of 1845-52, do not however seem to have many direct parallels further back in time.

Interest in past population structure has been invigorated by medical interest in localised haplotype variants and the genetic aetiology of certain diseases. Past population size is also an important parameter in on-going attempts to model past patterns of land cover used to forecast the effects of climate change (Harrison et al., 2018; Smith et al., 2016). In this case study we have demonstrated that archaeological data are essential to this science, but there is still much work to be done in developing robust proxies for past population size and structure. Alternative explanations for the trends in the archaeological data exist, such as systematic biases, behavioural change and decreasing visibility of later sites. However, population dynamics remain a straightforward explanation of the trends, especially given their gradual nature and their simultaneous occurrence in multiple contexts, even if the social, political and economic root causes of the dynamic were intertwined and complex. A challenge to our colleagues working in genomic studies is to open dialogue with those archaeologists and statisticians working towards a synthesis of long-term trends in the human past, and begin to unravel the demographic complexity that has the potential to explain so much about human societies.

\section{Data, code and materials}


316 The supplementary datasets contain all the ${ }^{14} \mathrm{C}$ data and meta-data needed to calculate the 317 density models used in this analysis. A full bibliographic index to these data is beyond the scope of this paper but readers can cross-reference the ${ }^{14} \mathrm{C}$ laboratory codes with the following sources:

Chapple, R. M. (2015) Irish Radiocarbon and Dendrochronological Dates,

https://sites.google.com/site/chapplearchaeology/irish-radiocarbon-dendrochronological-dates

Archaeological Site Index to Radiocarbon Dates from Great Britain and Ireland Council for

British Archaeology Radiocarbon

Index, archaeologydataservice.ac.uk/archives/view/c14_cba/

Digital Repository of Ireland Digital Heritage Collections,

https://repository.dri.ie/catalog/v6936m966

330

Updated versions of the software used for the density modelling (McLaughlin, 2018) are freely available from the corresponding author.

\section{Acknowledgements}

Maps were drawn using NaturalEarth (coastline) and SRTM (elevation) data; the locations of settlement sites were provided by the public Sites and Monuments Records of the Republic of Ireland and Northern Ireland. We thank the very many archaeologists - virtually all those working in Ireland - whose work we summarise here and the efforts of the Council for British Archaeology, Heritage Council (Ireland), Transport Infrastructure Ireland, Mr Robert Chapple, Ms Isabel Bennett, the National Monuments Service of the Department of Culture, Heritage and the Gaeltacht, The Royal Irish Academy, and the Northern Ireland Historic Environment Division, among others, to make these data easily accessible. We gratefully acknowledge Dr 
Russell McLaughlin and Mr Ross Byrne for discussions on genomics that have prompted us to write this short paper in response, and Mr Eóin Parkinson and Professor Jim Mallory for their thoughtful comments on the text. Editorial guidance and the informed and stimulating criticism from two anonymous reviewers helped us improve this paper.

\section{Funding}

EH is supported by an AHRC studentship

\section{References}

Armit, I., Swindles, G.T., Becker, K., Plunkett, G., Blaauw, M., 2014. Rapid climate change did not cause population collapse at the end of the European Bronze Age. Proceedings of the National Academy of Sciences 111, 17045-17049.

Bevan, A., Colledge, S., Fuller, D., Fyfe, R., Shennan, S., Stevens, C., 2017. Holocene fluctuations in human population demonstrate repeated links to food production and climate. Proceedings of the National Academy of Sciences.

Bronk Ramsey, C., 2017. Methods for Summarizing Radiocarbon Datasets. Radiocarbon, 125.

Byrne, R.P., Martiniano, R., Cassidy, L.M., Carrigan, M., Hellenthal, G., Hardiman, O., Bradley, D.G., McLaughlin, R.L., 2018. Insular Celtic population structure and genomic footprints of migration. PLOS Genetics 14, e1007152.

Cambell, E. 2001. Were the Scots Irish? Antiquity 75, 285-292.

Cassidy, L.M., Martiniano, R., Murphy, E.M., Teasdale, M.D., Mallory, J., Hartwell, B., Bradley, D.G., 2016. Neolithic and Bronze Age migration to Ireland and establishment of the insular Atlantic genome. Proceedings of the National Academy of Sciences 113, 368-373.

Chapple, R.M., 2015. Catalogue of Radiocarbon Determinations \& Dendrochronology Dates (December 2015 release). Oculus Obscura Press, Belfast.

Coyle-McClung, L., 2012. A palynological investigation of land-use patterns in first millennium AD Ireland. Queen's University Belfast.

Coyle-McClung, L., 2013. The Late Iron Age Lull - not so Late Iron Age after all! Emania 21, 73-83.

Cullen, L.M., 1974-5. Population Trends in Seventeenth-Century Ireland. Economic and Social Review 6, 149-165.

Dooley, A. 2007. The Plague and Its Consequences in Ireland. In L. K. Little (ed.) Plague and the End of Antiquity, Cambridge University Press, Cambridge, 215-230. 
Edinborough, K., Porčić, M., Martindale, A., Brown, T.J., Supernant, K., Ames, K.M., 2017. Radiocarbon test of demographic events in written and oral history. Proceedings of the National Academy of Sciences.

FitzPatrick, E. 2013. Native Enclosed Settlement and the Problem of the Irish 'Ring-fort'. Medieval Archaeology 53, 271-301.

Gilbert, E., O’Reilly, S., Merrigan, M., McGettigan, D., Molloy, A.M., Brody, L.C., Bodmer, W., Hutnik, K., Ennis, S., Lawson, D.J., Wilson, J.F., Cavalleri, G.L., 2017. The Irish DNA Atlas: Revealing Fine-Scale Population Structure and History within Ireland. Scientific Reports 7, 17199.

Goldstone J. 1991. Revolution and Rebellion in the Early Modern World. University of California Press, Berkeley, California.

Guiry, E., Beglane, F., Szpak, P., Schulting, R., McCormick, F., Richards, M.P., 2018. Anthropogenic changes to the Holocene nitrogen cycle in Ireland. Science Advances 4.

Hall, V. A., Pilcher, J. R. and McCormac, F. G. 1993. Tephra-dated lowland landscape history of the north of Ireland, AD 750-1150. New Phytologist 125, 193-202.

Harrison, S.P., Stocker, B.D., Goldewijk, K.K., Kaplan, J.O., Braconnot, P., 2018. Do we need to include anthropogenic land-use and land-cover changes in paleoclimate simulations? Past Global Changes Magazine 26, 4-5.

Jørgensen, E.K., 2018. The palaeodemographic and environmental dynamics of prehistoric Arctic Norway: An overview of human-climate covariation. Quaternary International In press.

Knudson, K.J., O’Donnabhain, B., Carver, C., Cleland, R., Price, T.D., 2012. Migration and Viking Dublin: paleomobility and paleodiet through isotopic analyses. Journal of Archaeological Science 39, 308-320.

Leslie, S., Winney, B., Hellenthal, G., Davison, D., Boumertit, A., Day, T., Hutnik, K., Royrvik, E.C., Cunliffe, B., Wellcome Trust Case Control, C., International Multiple Sclerosis Genetics, C., Lawson, D.J., Falush, D., Freeman, C., Pirinen, M., Myers, S., Robinson, M., Donnelly, P., Bodmer, W., 2015. The fine-scale genetic structure of the British population. Nature 519, 309.

McClatchie, M., McCormick, F., Kerr, T.R., O’Sullivan, A., 2015. Early medieval farming and food production: a review of the archaeobotanical evidence from archaeological excavations in Ireland. Vegetation History and Archaeobotany 24, 179-186.

McCormick, F., 2008. The decline of the cow: agricultural and settlement change in early medieval Ireland. Peritia 20, 209-224.

McEvoy, B., Brady, C., Moore, L.T., Bradley, D.G., 2006. The scale and nature of Viking settlement in Ireland from Y-chromosome admixture analysis. European Journal Of Human Genetics 14, 1288.

McLaughlin, R., Hannah, E., Coyle-McClung, L., 2018. Frequency analyses of historical and archaeological datasets reveal the same pattern of declining sociocultural activity in 9th to 10th Century CE Ireland. Cliodynamics 9, 1-24.

McLaughlin, T.R., 2018. On applications of space-time modelling with open-source 14C age calibration. Journal of Archaeological Method and Theory. 
McLaughlin, T.R., Whitehouse, N.J., Schulting, R.J., McClatchie, M., Barratt, P., Bogaard, A., 2016. The Changing Face of Neolithic and Bronze Age Ireland: A Big Data Approach to the Settlement and Burial Records. Journal of World Prehistory 29, 117-153.

Morin, J., Lepofsky, D., Ritchie, M., Porčić, M., Edinborough, K., 2018. Assessing continuity in the ancestral territory of the Tsleil-Waututh-Coast Salish, southwest British Columbia, Canada. Journal of Anthropological Archaeology 51, 77-87.

426 O'Brien, E. 2009. Pagan or Christian? Burial in Ireland during the 5th to 8th centuries AD. In 427 N. Edwards (ed.) The archaeology of the early medieval Celtic churches, Maney, Leeds, 189214.

429 Oh, Y., Conte, M., Kang, S., Kim, J., Hwang, J., 2017. Population Fluctuation and the Adoption 430 of Food Production in Prehistoric Korea: Using Radiocarbon Dates as a Proxy for Population 431 Change. Radiocarbon, 1-10.

432 O'Sullivan, A., McCormick, F. Kerr, T. R. and Harney, L. 2014. Early medieval Ireland, AD 400-1100: the evidence from archaeological excavations. Royal Irish Academy, Dublin.

O’Sullivan, A. and McCormick, F. 2017. Early medieval Ireland: investigating social, economic and settlement change, AD 400-1100. Transport Infrastructure Ireland, Dublin.

Palmisano, A., Bevan, A., Shennan, S., 2017. Comparing archaeological proxies for long-term population patterns: An example from central Italy. Journal of Archaeological Science 87, 5972 .

Reimer, P.J., Bard, E., Bayliss, A., Beck, J.W., Blackwell, P.G., Bronk Ramsey, C., Buck, C.E., Cheng, H., Edwards, R.L., Friedrich, M., 2013. IntCal13 and Marine13 radiocarbon age calibration curves 0-50,000 years cal BP. Radiocarbon 55, 1869-1887.

Robinson, P., 1984. The Plantation of Ulster. Gill and Macmillan, Dublin.

Ruddiman, W.F., 2003. The anthropogenic greenhouse era began thousands of years ago. Climatic change 61, 261-293.

Russell, J.C. 1958. Late ancient and medieval population. Transactions of the Americian Philsophical Society 48, Part 3, 1-152.

Smith, M.C., Singarayer, J.S., Valdes, P.J., Kaplan, J.O., Branch, N.P., 2016. The biogeophysical climatic impacts of anthropogenic land use change during the Holocene. Clim. Past 12, 923-941.

Timpson, A., Colledge, S., Crema, E., Edinborough, K., Kerig, T., Manning, K., Thomas, M.G., Shennan, S., 2014. Reconstructing regional population fluctuations in the European Neolithic using radiocarbon dates: a new case-study using an improved method. Journal of Archaeological Science 52, 549 - 557. 